\title{
Listen to the Experts: How Family Firms are Surviving the Pandemic
}

\author{
Kimberly Eddleston (Northeastern University)
}

KEYWORDS: Leadership, Family Business, crisis management, COVID-19.

It has been almost a year since the Covid pandemic rocked the world. While we have seen some family businesses forced to close their doors forever, others have successfully pivoted their business, and have focused on surviving the crisis. Some long-standing family businesses have compared the current pandemic to crises they have endured in the past, looking to their history for strength and inspiration. Some family businesses have even found ways to prosper, turning "lemons into lemonade."

To offer insight on mistakes made and lessons learned, we sought advice from four FamilyBusiness.org board members who are renowned for their research and work with family businesses: Alfredo De Massis, Nadine Kammerlander, Rania Labaki, and Torsten Pieper. This conversation is aimed to help business-owning families understand common mistakes in dealing with the pandemic and the unique advantages family businesses can employ. It also offers examples of how some family businesses have pivoted and shown resilience.

\section{What mistakes have you seen family businesses make in dealing with the Covid pandemic?}

Nadine: "Hibernating -- or just reducing costs, applying for government support and hoping for the crisis to end soon. This strategy might be effective for a short-term crisis, but not for those more long-term. For longer crises, firms need to be adaptive and search for new business opportunities. For example, a family business I have been working with recently started to manufacture face masks. Although the business has traditionally produced equipment for industrial companies, when the pandemic hit they realized that face masks were going to play an important role in the workplace. So they quickly invested in machines, product development and certification. Their successful efforts built on their resiliency, past experiences, and the passion of the family CEO who has always been able to inspire his employees."

Alfredo: "The pandemic offers family businesses the opportunity to embrace a real long-term perspective. Thus, one of the main mistakes I have seen is focusing too much on short-term financial priorities. Of course the Covid-19 pandemic, like any crisis, has brought about cash challenges and new types of risks that jeopardize the economic utilities of family firms. But the family business leaders who reacted more successfully during the first wave of this pandemic have been those who prioritized their non-economic goals instead, and relied on their legacy and family values. Focusing only on financial aspects when the bottom line suffers would simply be wrong. Signaling the family firm's identity and reputation resulting from the family's noneconomic goals, and drawing as much as possible on the family's values and tradition, allowed many successful family firms I worked with to retain their most important (strategic) linkages throughout the pandemic, increasing their resilience to the crisis. When things get tough, family firms have a unique opportunity to convey to the wider community of their stakeholders that their "essence" is different from that of non-family firms, as they look beyond just numbers on a balance sheet, and this typically helps to re-launch the family and the business after the crisis ends."

Torsten: "Building on these points, many family businesses refused to adjust their orientation to the new reality - something referred to as 'orientation lock.' They were unwilling to adapt or change their business model to one that would fit the current environment. Thus, to borrow an analogy from our dear colleague, Pramodita Sharma, the pandemic could be seen as a magnifying glass whereby families that worked well
Copyright @ 2021 The Authors. Entrepreneur \& Innovation Exchange is published at EIX.org. This is an open access article under the terms of the Creative Commons Attribution-NoDerivs License, which permits use and distribution in any medium, provided the original work is properly cited and no modifications or adaptations are made. View EIX.org Authorship Terms at https://eix.org/terms
FamilyBusiness 
together before continued to stand strong, while those fraught with conflict before the pandemic continued to experience ruptures. It is therefore clear that many family businesses underestimated the significant amount of deliberate effort and constant work required to remain connected while staying physically apart (due to social distancing measures, travel and meeting restrictions, etc.). Just the fact that we are family will not keep us together in the long run. Relationships require constant work and investment."

\section{What advantages do family businesses have over non-family businesses in surviving the pandemic?}

Rania: "Their past! The stories and myths behind the business can serve as a competitive strategic resource in times of crisis. They often offer valuable lessons about how the family business managed to overcome past challenges, which could be replicated or adapted to the current crisis. They remind family members about the fundamental values that should guide their behavior in critical times. They are also sources of hope and optimism around the capacity of resilience of the family business ${ }^{[1]}$ and the possibility of a bright future. As such, historical narratives tend to lessen the anxiety that can paralyze or delay decision-making during a crisis, offering inspiration to family businesses that pushes them through a crisis."

Torsten: "Four common advantages that we have seen among family businesses that deal effectively with the crisis are: sweat equity, patient capital, slack resources, and putting employees' and customers' safety first. During a crisis, it's "all hands on deck" for family businesses. Family members who were not employed in the business spontaneously offered to help to keep the business going, offering their sweat equity, when non-family employees were sent home for safety reasons. Similar to what Rania noted, family businesses rely on patient capital - they think in generations rather than in quarterly cycles. I recall a member of a sixth-generation family business saying 'We have gone through two world wars, numerous recessions, depressions, downturns, and other traumatic events.... and we are still standing here today. I'm confident we will also get through this crisis.' That brings me to my next family business advantage slack resources. When times are good, many chastise family businesses for not being efficient enough (they have too much "slack" and redundancies built into their system). But when the going gets tough (as with the current pandemic), their 'systemic redundancies' allow them to significantly reduce the detrimental impact of supply chain problems and other disruptions to their activities and communities. Finally, family businesses have put employees' and customers' safety first: Most family businesses would rather accept a temporary drop in performance (and fewer dividends as a result) than compromise the health and safety of their employees and customers. It's a non-debatable value to many family businesses. And as Clayton Christensen (the grand master of disruption) was known to say: 'It's easier to hold your principles 100 percent of the time than it is to hold them 98 percent of the time."

Alfredo: "As I recently explain in a Journal of Management Studies ${ }^{[2]}$ article co-authored with Emanuela Rondi, long-established family businesses are typically better equipped than non-family firms to absorb and react to a crisis and its aftermath. Family businesses are often able to draw on their history to find strategies they have used in the past to overcome and survive previous family and/or business crises. The core values of the family, that transfer from one generation to the next, also serve as a compass to orient their actions during times of uncertainty. Therefore, maintaining and preserving the family firm's traditions and being strongly anchored to the values of the owning family are advantages for family firms struggling through the Covid-19 crisis. In fact, some family firms I work with are seeking to overcome the crisis by rediscovering or perpetuating their past and consolidating their traditions through innovation."

\section{Any other lessons you can share based on your work with family businesses?}

Nadine: "Family businesses often have a good financial structure that helps them overcome times of reduced revenue. Thus, while they are often criticized for being overly conservative and not leveraged enough during economic booms, their long-term outlook makes them well-poised to weather crises. Also, business-owning families that are able to quickly make decisions, adapt, and implement changes appear to have a real advantage in navigating crises with some actually turning a crisis into business 
opportunities."

Rania: "The current pandemic has demonstrated how important it is for family businesses to be able to quickly adapt their business models and reinvent themselves. A family business I find quite inspiring is the Fernand Hosri Group(https://hosriholding.com/) from Lebanon, a group of companies located in the Middle East and Europe. They saw this crisis as an opportunity to rediscover new territories and to make organizational changes that would improve their efficiency. For example, the family took advantage of reliable, long-term relationships with their partners to enter new markets. They also saw the crisis as a wakeup call to develop a more agile organizational structure, and implemented a cross-sharing model for each area of expertise. This meant that instead of having a finance or marketing department at each company in the group, they decided to have one finance department or one marketing department that served all the different companies. This means that people who once provided marketing solely for the chocolate business now also do marketing for the medical devices, hygienic products and other offerings sold by the Hosri's companies...so everyone becomes more knowledgeable about all these companies. Additionally, they decided to sell such services or cater these services to other companies not managed by the group."

Torsten: "I've been quite inspired by family businesses that have not only resisted the 'orientation lock' but have actively sought opportunities during the current pandemic. One well-known example that comes to mind is Pernod Ricard, which quickly switched its alcohol production lines from making vodka and gin to producing hand sanitizer - which was in alarmingly short supply. Many other distilleries around the globe have done the same."

\section{Biographies of contributors:}

Alfredo De Massis is a Professor of Entrepreneurship \& Family Business at the Free University of BozenBolzano, Italy. He serves as advisor to family enterprises and policy makers, is Editor of the influential journal Entrepreneurship Theory \& Practice (in the Financial Times rank of top 50 journals), is Associate Editor of Family Business Review, and serves on the boards of public and private organizations internationally.
Nadine Kammerlander is a professor of family business at WHU - Otto Beisheim School of Management, Germany where she also serves as Director of the Institute of Family Businesses and Mittelstand. Nadine is an Associate Editor of Family Business Review; she is particularly interested in studying innovation, leadership, and governance in family businesses and family offices.

Rania Labaki is an Associate Professor and Director of the EDHEC Family Business Research Centre. She is also a Family Business Fellow at Cornell University. Rania serves as an IFERA board member, Lansberg Gersick \& Associates advisor, and Entrepreneurship Research Journal co-editor. Her recent interests revolve around the interplay between emotional dynamics and family business behavior.

Torsten M. Pieper is Associate Professor of Management in the Belk College of Business at UNC Charlotte, President of the International Family Enterprise Research Academy (IFERA), and Editor-inChief of the Elsevier title Journal of Family Business Strategy (JFBS).

[1] Labaki, R. (2020). The family business: A valuable model of resilience in extraordinary times. [https://www.c ampdenfb.com/article/family-business-valuable-modelresilience-extraordinary-times]. CampdenFB.

[2] De Massis A., Rondi E. (2020). Covid-19 and the future of family business research, Journal of Management Studies, 57(8), 1727-1731. DOI: 10.1111/joms.12632 